Article

\title{
Antidiarrheal Thymol Derivatives from Ageratina glabrata. Structure and Absolute Configuration of 10-Benzoyloxy-8,9-epoxy-6- hydroxythymol Isobutyrate
}

\author{
Celia Bustos-Brito ${ }^{1, *}$, Valeria J. Vázquez-Heredia ${ }^{1}$, Fernando Calzada ${ }^{2}$, Lilian Yépez-Mulia ${ }^{3}$, \\ José S. Calderón ${ }^{1}$, Simón Hernández-Ortega ${ }^{1}$, Baldomero Esquivel ${ }^{1}$, \\ Normand García-Hernández ${ }^{4}$ and Leovigildo Quijano ${ }^{1, *}$ \\ 1 Instituto de Química, Universidad Nacional Autónoma de México, Circuito Exterior, Ciudad Universitaria, \\ D.F. 04510, Mexico; la_campanella@comunidad.unam.mx (V.J.V.-H.); uscalder@unam.mx (J.S.C.); \\ shernandezortega@gmail.com (S.H.-O.); baldo@unam.mx (B.E.) \\ 2 UIM en Farmacología, 2o Piso CORCE, UMAE Hospital de Especialidades, Centro Médico Nacional \\ Siglo XXI, IMSS, Av. Cuauhtémoc 330, Col. Doctores, México, D.F. 06725, Mexico; fercalber10@gmail.com \\ 3 UIM en Enfermedades Infecciosas y Parasitarias, UMAE Hospital de Pediatría, Centro Médico Nacional \\ Siglo XXI, IMSS, Av. Cuauhtémoc 330, Col. Doctores, México, D.F. 06725, Mexico; lilianyepez@yahoo.com \\ 4 UIM en Genética Humana, UMAE Hospital de Pediatría, Centro Médico Nacional Siglo XXI, IMSS, \\ Centro Médico Nacional Siglo XXI, IMSS, Av. Cuauhtémoc 330, Col. Doctores, México, D.F. 06725, Mexico; \\ normandgarcia@gmail.com \\ * Correspondence: bustosbritocelia@comunidad.unam.mx (C.B.-B.); quijano@unam.mx (L.Q.); \\ Tel.: +52-55-5622-4411 (L.Q.)
}

Academic Editor: Thomas J. Schmidt

Received: 7 July 2016; Accepted: 24 August 2016; Published: 12 September 2016

\begin{abstract}
Chemical investigation of the leaves from Ageratina glabrata yielded four new thymol derivatives, namely: 10-benzoyloxy-8,9-dehydro-6-hydroxythymol isobutyrate (4), 10-benzoyloxy-8, 9-dehydrothymol (5), 10-benzoyloxythymol (6) and 10-benzoyloxy-6,8-dihydroxy-9-isobutyryloxythymol (7). In addition, (8S)-10-benzoyloxy-8,9-epoxy-6-hydroxythymol isobutyrate (1), together with other two already known thymol derivatives identified as 10-benzoyloxy-8,9-epoxy6-methoxythymol isobutyrate (2) and 10-benzoyloxy-8,9-epoxythymol isobutyrate (3) were also obtained. In this paper, we report the structures and complete assignments of the ${ }^{1} \mathrm{H}$ and ${ }^{13} \mathrm{C}-\mathrm{NMR}$ data of compounds 1-7, and the absolute configuration for compound 1, unambiguously established by single crystal $X$-ray diffraction, and evaluation of the Flack parameter. The in vitro antiprotozoal assay showed that compound $\mathbf{1}$ and its derivative 1a were the most potent antiamoebic and antigiardial compounds. Both compounds showed selectivity and good antiamoebic activity comparable to emetine and metronidazole, respectively, two antiprotozoal drugs used as positive controls. In relation to anti-propulsive effect, compound $\mathbf{1}$ and 1a showed inhibitory activity, with activities comparable to quercetin and compound 9, two natural antipropulsive compounds used as positive controls. These data suggest that compound $\mathbf{1}$ may play an important role in antidiarrheal properties of Ageratina glabrata.
\end{abstract}

Keywords: Ageratina glabrata; thymol derivatives; antiprotozoal and antidiarrheal properties

\section{Introduction}

Ageratina glabrata (Kunth) R.M. King \& H. Rob., Asteraceaea, is a shrub endemic to Mexico widely distributed throughout the country. The importance of $A$. glabrata in Mexican traditional medicine is indicated by its use for treating pain and gastrointestinal disorders associated with bacterial infections. 
However, chemical studies of the species are scarce. Previous phytochemical studies of $A$. glabrata show that its non-polar solvent extracts are composed mainly by thymol and eudesmane derivatives [1-3] while the essential oil is constituted mainly by monoterpenes [4]. On the other hand, evaluation for antibacterial activity of extracts of $A$. glabrata against antibiotic resistant pathogenic bacteria showed that the non-polar extract is the most active [5]. Preliminary studies on analgesic effect of extracts of A. glabrata in the hot plate test showed a moderate effect [6].

As part of our search for antiprotozoal and antidiarrheal compounds in Ageratina species, we have previously published our results on A. cylindrica $[7,8]$. The aim of this paper is to report on the isolation, structural characterization, and the antiprotozoal and antipropulsive evaluation of the thymol derivatives 1-4 and 7. Compounds $4-7$ are new thymol derivatives, while compounds $1-3$, have been previously reported from the same species, although their data were poorly described [3]. The chemical structures of the compounds isolated were established by spectroscopic methods, mainly MS and 1D, 2D NMR experiments (DEPT, COSY, NOESY, HSQC, HMBC), while the structure and absolute configuration of $\mathbf{1}$, were confirmed by single crystal X-ray diffraction.

\section{Results and Discussion}

Detailed investigation of a dichloromethane extract of the leaves of A. glabrata resulted in the isolation of seven thymol derivatives, together with the known flavonoid pectolinaringenin [9] and benzoic acid. Compound 1 (Figure 1) was isolated as colorless crystals, whose molecular composition was determined as $\mathrm{C}_{21} \mathrm{H}_{22} \mathrm{O}_{6}$ on the basis of its HRDARTMS molecular ion at $\mathrm{m} / \mathrm{z}$ $371.15003[\mathrm{M}+\mathrm{H}]^{+}$(calculated for $\mathrm{C}_{21} \mathrm{H}_{23} \mathrm{O}_{6}$ 371.14946), indicating nine degrees of unsaturation in the molecule. Its IR spectrum showed characteristic absorptions for hydroxyl $\left(3599 \mathrm{~cm}^{-1}\right)$ and ester groups $\left(1757,1723 \mathrm{~cm}^{-1}\right)$.
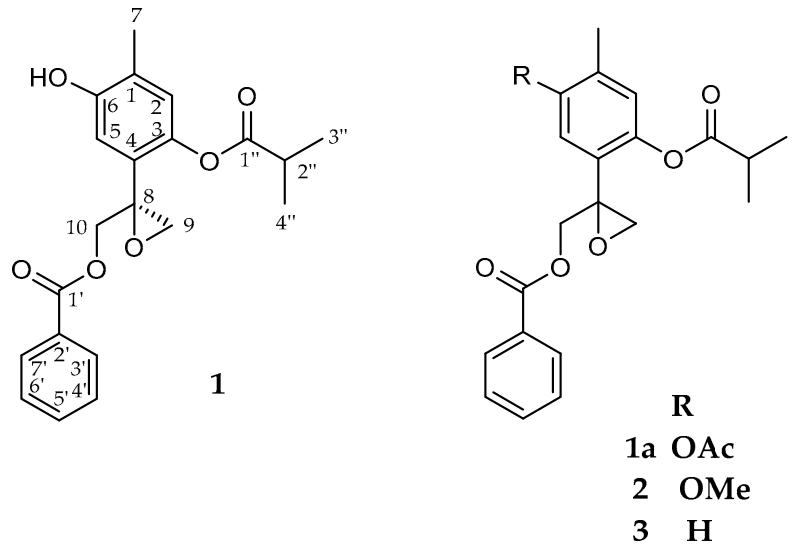

Figure 1. Chemical structure of 1-3.

The ${ }^{13} \mathrm{C}$-NMR spectrum of 1 showed 19 resonances representing 21 carbon atoms due to three $\mathrm{CH}_{3}$, two $\mathrm{CH}_{2}$, eight $\mathrm{CH}$ groups (included two symmetric ones), and eight quaternary $\mathrm{C}$ atoms, according to DEPT and HSQC experiments. The ${ }^{1} \mathrm{H}-\mathrm{NMR}$ spectrum exhibited in the aromatic region two one-proton signals as singlets at $\delta 6.79$ and 6.94 assigned to $\mathrm{H}-2$ and $\mathrm{H}-5$, respectively, indicating a tetra-substitution of the thymol ring. Characteristic resonances in the aromatic region at $\delta 7.97(2 \mathrm{H}), 7.55(1 \mathrm{H})$ and 7.40 $(2 \mathrm{H})$, indicated the presence of a benzoate moiety, while a heptet $\delta 2.83(1 \mathrm{H}, J=7.2 \mathrm{~Hz})$ and two doublets at $\delta 1.312$ and $1.307(3 \mathrm{H}, J=7.2 \mathrm{~Hz})$ revealed the presence of an isobutyrate group in the molecule. Two AB spin systems with doublets at $\delta 3.12,2.86(J=5.2 \mathrm{~Hz})$ and $4.77,4.48(J=12.3 \mathrm{~Hz})$ due to the C-9 and C-10 methylene protons supported the presence of the oxirane and the benzoate ester functionalities, respectively.

The relative position of the ester groups was established via correlations observed in the HMBC and NOESY experiments, indicating that the benzoate was attached at C-10 and isobutyrate at C-3. 
Accordingly the C-10 methylene protons at $\delta 4.77$ and 4.48 showed a ${ }^{3} J$ correlation peak with the carbonyl carbon at $\delta 166.3$, which in turn showed correlation peaks with the aromatic protons signal at $\delta 7.97\left(\mathrm{H}-3^{\prime} / 7^{\prime}\right)$ in the HMBC spectrum. On the other hand the NOESY experiment showed interactions between the isobutyrate methyl protons (H-3", H-4") and the methylene protons at C-9, and C-10, while the aromatic proton $\mathrm{H}-2$ showed couplings with $\mathrm{H}-3^{\prime \prime}, \mathrm{H}-4^{\prime \prime}$, and the methyl protons at C-7. Therefore the isobutyrate group must be attached at C-3. Further HMBC long range couplings of the C-10 methylene protons with the quaternary carbon at $\delta 57.3(\mathrm{C}-8)$ and the methylene carbon at $\delta 51.3$ (C-9), suggested the presence of the oxirane group at C-8-C-9. Acetylation of $\mathbf{1}$ with pyridine and acetic anhydride led to the acetate derivative 1a (Figure 1). The ${ }^{1} \mathrm{H}$ and ${ }^{13} \mathrm{C}-\mathrm{NMR}$ spectra (Table 1) of $\mathbf{1 a}$ displayed features similar to those of $\mathbf{1}$, except for the presence of a sharp methyl singlet at $\delta 2.31$ in the ${ }^{1} \mathrm{H}-\mathrm{NMR}$ spectrum, and two extra carbon resonances $(\delta 168.9$ and 20.8$)$ in the ${ }^{13} \mathrm{C}-\mathrm{NMR}$ spectrum, associated with the presence of the acetate group. Based on all above data, the structure of compound 1, was established as 10-benzoyloxy-8,9-epoxy-6-hydroxythymol isobutyrate.

Table 1. NMR spectroscopic data $\left({ }^{1} \mathrm{H} 400 \mathrm{MHz},{ }^{13} \mathrm{C} 100 \mathrm{MHz}, \mathrm{CDCl}_{3}\right)$ of $\mathbf{1}$ and $\mathbf{1 a}$.

\begin{tabular}{|c|c|c|c|c|c|}
\hline \multirow{2}{*}{ Position } & \multicolumn{3}{|c|}{1} & \multicolumn{2}{|c|}{ 1a } \\
\hline & $\delta_{C}$, Type & $\delta_{H}(J$ in $\mathbf{H z})$ & НМВС & $\delta_{C}$, Type & $\delta_{H}(J$ in $\mathbf{H z})$ \\
\hline 1 & $126.2, \mathrm{C}$ & & & $132.2, \mathrm{C}$ & \\
\hline 2 & $124.8, \mathrm{CH}$ & $6.79, \mathrm{~d}(0.8)$ & $1,3,4,6,7$ & $125.0, \mathrm{CH}$ & $6.96, \mathrm{brs}$ \\
\hline 3 & 141.7, C & & & $146.2, \mathrm{C}$ & \\
\hline 4 & $127.2, \mathrm{C}$ & & & $127.9, \mathrm{C}$ & \\
\hline 5 & $114.8, \mathrm{CH}$ & $6.94, \mathrm{~s}$ & $1,3,6,8$ & 122.7, $\mathrm{CH}$ & 7.23. s \\
\hline 6 & $152.1, \mathrm{C}$ & & & 147.0, C & \\
\hline 7 & $15.8, \mathrm{CH}_{3}$ & $2.18, \mathrm{~s}$ & $1,2,6$ & 16.3, $\mathrm{CH}_{3}$ & $2.17, \mathrm{~s}$ \\
\hline 8 & $57.3, \mathrm{C}$ & & & $56.9, \mathrm{C}$ & \\
\hline $9 a$ & $51.3, \mathrm{CH}_{2}$ & $3.12, \mathrm{~d}(5.2)$ & $4,8,10$ & $51.2, \mathrm{CH}_{2}$ & $3.11, \mathrm{~d}(5.2)$ \\
\hline $9 b$ & & $2.86, \mathrm{~d}(5.2)$ & $4,8,10$ & & $2.87, \mathrm{~d}(5.2)$ \\
\hline $10 \mathrm{a}$ & 65.6, $\mathrm{CH}_{2}$ & $4.77, \mathrm{~d}(12.3)$ & $1^{\prime}, 4,8,9$ & $65.9, \mathrm{CH}_{2}$ & $4.76, \mathrm{~d}(12.2)$ \\
\hline $10 \mathrm{~b}$ & & $4.48, \mathrm{~d}(12.3)$ & $1^{\prime}, 4,8,9$ & & $4.47, \mathrm{~d}(12.2)$ \\
\hline $1^{\prime}$ & 166.3, C & & & 166.1, C & \\
\hline $2^{\prime}$ & 129.7, C & & & 129.0, C & \\
\hline $3^{\prime}$ & $129.8, \mathrm{CH}$ & $7.97, \mathrm{~m}$ & $1^{\prime}, 5^{\prime}$ & $129.9, \mathrm{CH}$ & $7.97, \mathrm{~m}$ \\
\hline $4^{\prime}$ & $128.5, \mathrm{CH}$ & $7.40, \mathrm{~m}$ & $3^{\prime}, 5^{\prime}, 7^{\prime}$ & $128.5, \mathrm{CH}$ & $7.42, \mathrm{~m}$ \\
\hline $5^{\prime}$ & $133.4, \mathrm{CH}$ & $7.55, \mathrm{tt}(7.5,1.3)$ & $3^{\prime}, 7^{\prime}$ & $133.3, \mathrm{CH}$ & $7.55, \mathrm{tt}(7.4,1.2)$ \\
\hline $6^{\prime}$ & $128.5, \mathrm{CH}$ & $7.40, \mathrm{~m}$ & $3^{\prime}, 5^{\prime}, 7^{\prime}$ & $128.5, \mathrm{CH}$ & $7.42, \mathrm{~m}$ \\
\hline $7^{\prime}$ & $129.8, \mathrm{CH}$ & 7.97, m & $1^{\prime}, 5^{\prime}$ & $129.9, \mathrm{CH}$ & $7.97, \mathrm{~m}$ \\
\hline $1^{\prime \prime}$ & $176.2, \mathrm{C}$ & & & $175.3, \mathrm{C}$ & \\
\hline $2^{\prime \prime}$ & $34.3, \mathrm{CH}$ & 2.83, hep (7.2) & $1^{\prime \prime}, 3^{\prime \prime}, 4^{\prime \prime}$ & $34.3, \mathrm{CH}$ & 2.84, hep (7.2) \\
\hline $3^{\prime \prime}, 4^{\prime \prime}$ & $19.1,19.2, \mathrm{CH}_{3}$ & $1.312,1.307 \mathrm{~d}(7.2)$ & $1^{\prime \prime}, 2^{\prime \prime}$ & $19.0,19.1, \mathrm{CH}_{3}$ & $1.31,1.32, \mathrm{~d}(7.2)$ \\
\hline $6-\mathrm{OH}$ & & 5.78, brs & & & \\
\hline $\mathrm{COCH}_{3}$ & & & & $20.8, \mathrm{CH}_{3}$ & 2.31 \\
\hline$\underline{\mathrm{COCH}}_{3}$ & & & & $168.9, \mathrm{C}$ & \\
\hline
\end{tabular}

Concerning the absolute configuration (AC) of chiral thymol derivatives, the only reported case is that of (8S)-8,9-epoxy-6-hydroxy-10-benzoyloxy-7-oxothymol isobutyrate (9), isolated from A. cylindrica. Its $\mathrm{AC}$ was established as $8 \mathrm{~S}$ by vibrational circular dichroism spectroscopy in combination with density functional theory (DFT) calculations and evaluation of the Flack and Hooft X-ray parameters [7]. Evaluation of the Flack X-ray parameter for compound 1 defined its AC as 8S, consistent with that of compound $\mathbf{9}$, with a similar structure. For this purpose a single crystal of $\mathbf{1}$ was mounted on an X-ray diffractometer equipped with $\mathrm{CuK} \alpha$ monochromated radiation and collected at $150 \mathrm{~K}$. Compound 1 crystallized as two crystallographically independent molecules, in the monoclinic system, space group P2(1). The structure was solved by direct methods using a full-matrix least-squares and refined to a discrepancy index of $4.23 \%$. The absolute configuration of $\mathbf{1}$ was determined using an anomalous dispersion effects in diffraction measurements on the crystal, the Flack parameter [10], which for 
the enantiomer shown in Figure 2 was $x=-0.03(15)$, thus permitting confirmation of the proposed structure, and definition of the $(8 S)$ configuration (Figure 2). In the structure the oxirane ring forms a dihedral angle of $56.3(2)^{\circ}$ and $55.7(2)^{\circ}$ with the phenol group in both structures. Crystallographic data (excluding structure factors) have been deposited with the Cambridge Crystallographic Data Centre under the reference number CCDC 1490853 contains the supplementary crystallographic data for this paper. These data can be obtained free of charge via http:/ / www.ccdc.cam.ac.uk/conts/retrieving. html (or from the CCDC, 12 Union Road, Cambridge CB2 1EZ, UK; Fax: +44 1223 336033; E-mail: deposit@ccdc.cam.ac.uk).

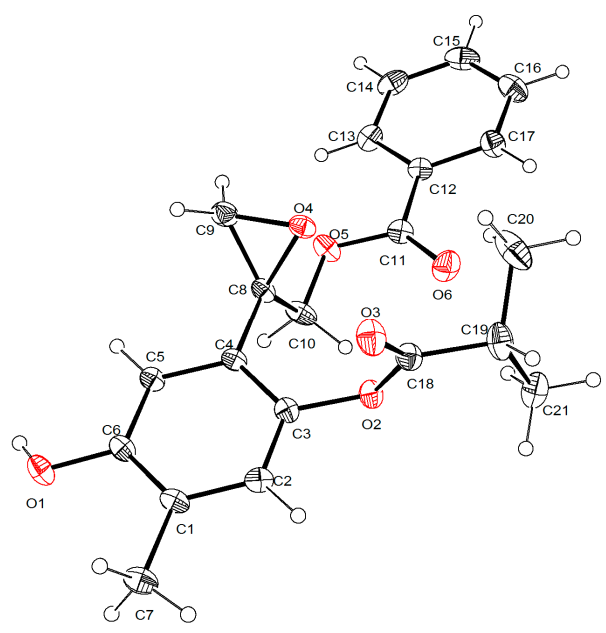

Figure 2. X-ray crystal structure of (+)-(8S)-10-benzoil-oxy-8,9-epoxy-6-hydroxy thymol isobutyrate (1).

It is necessary to point out that IR and ${ }^{1} \mathrm{H}-\mathrm{NMR}$ data of compound $\mathbf{1}$, were similar to those published for eupaglabrin, a thymol derivative with an odd structure isolated from the same species [1]. Its structure was established based mainly on chemical degradation and low resolution $60 \mathrm{MHz}{ }^{1} \mathrm{H}-\mathrm{NMR}$ data. Years later, a compound with the structure $\mathbf{1}$ and similar spectroscopic data, was also published. Nonetheless, spectroscopic data were limited to incomplete ${ }^{1} \mathrm{H}-\mathrm{NMR}$ and some interchanged assignments [3]. In conclusion, the chemical structure and the absolute configuration of the thymol derivative previously reported from A. glabrata [1,3], must be represented by the stereostructure 1 .

Compound 2 (Figure 1), was isolated in minute quantities, and identified as the methyl ether derivative of 1. Its HRDARTMS showed a pseudo-molecular ion peak at $m / z 385.16429[\mathrm{M}+\mathrm{H}]^{+}$, in agreement with a molecular formula $\mathrm{C}_{22} \mathrm{H}_{24} \mathrm{O}_{6}$. (calculated for $\mathrm{C}_{22} \mathrm{H}_{25} \mathrm{O}_{6}, 385.16511$ ). The NMR spectroscopic data of compound 2 (Table 2) were similar to those of $\mathbf{1}$, except for de presence of the methoxy group with signals at $\delta_{\mathrm{H}} 3.82$ and $\delta_{\mathrm{C}} 55.9$ in its ${ }^{1} \mathrm{H}$ and ${ }^{13} \mathrm{C}-\mathrm{NMR}$ spectra, respectively, in addition to the downfield shift of the C6 signal from 152.1 to $155.6 \mathrm{ppm}$, indicative of the metoxy group at that position. Thus, compound $\mathbf{2}$ was identified as the methyl ether derivative of compound 1. Methylation of 1, using iodomethane afforded compound 2, spectroscopically identical with the isolated compound, allowing the complete NMR assignments.

Spectroscopic data indicated that compound 3 (Figure 1) corresponded to the 6-deoxy derivative of 1. Its molecular composition $\mathrm{C}_{21} \mathrm{H}_{22} \mathrm{O}_{5}$ was deduced on the basis of its HRDARTMS pseudo-molecular ion peak at $m / z 355.15516[\mathrm{M}+\mathrm{H}]^{+}$, (calculated for $\left.\mathrm{C}_{21} \mathrm{H}_{23} \mathrm{O}_{5}, 355.15455\right)$, and ${ }^{13} \mathrm{C}-\mathrm{NMR}$, DEPT, and HSQC experiments. The ${ }^{1} \mathrm{H}-\mathrm{NMR}$ spectrum (Table 2), showed in the aromatic region three one-proton resonances at $\delta 6.88(\mathrm{brd}, J=0.7 \mathrm{~Hz}), 7.43(\mathrm{~d}, J=7.8)$ and $7.07(\mathrm{ddd}, J=7.8,1.6,0.7 \mathrm{~Hz})$ assigned to $\mathrm{H}-2$, H-5 and H-6 of the thymol moiety, respectively, indicating a trisubstitution pattern of the thymol ring. 
Table 2. NMR spectroscopic data $\left({ }^{1} \mathrm{H} 400 \mathrm{MHz},{ }^{13} \mathrm{C} 100 \mathrm{MHz}, \mathrm{CDCl}_{3}\right)$ of 2 and 3.

\begin{tabular}{|c|c|c|c|c|}
\hline \multirow{2}{*}{ Position } & \multicolumn{2}{|c|}{2} & \multicolumn{2}{|r|}{3} \\
\hline & $\delta_{C}$, Type & $\delta_{H}(J$ in $\mathbf{H z})$ & $\delta_{C}$, Type & $\delta_{H}(J$ in $\mathbf{H z})$ \\
\hline 1 & $128.6, \mathrm{C}$ & & $140.0, \mathrm{C}$ & \\
\hline 2 & 124.6, CH & 6.83, brs & $123.1, \mathrm{CH}$ & 6.88, brd $(0.7)$ \\
\hline 3 & 141.6, C & & $148.7, \mathrm{C}$ & \\
\hline 4 & $126.9, \mathrm{C}$ & & $126.1, \mathrm{C}$ & \\
\hline 5 & $109.9, \mathrm{CH}$ & $6.97, \mathrm{~s}$ & $128.9, \mathrm{CH}$ & $7.43, \mathrm{~d}(7.8)$ \\
\hline 6 & $155.6, \mathrm{C}$ & & $126.8, \mathrm{CH}$ & 7.07, ddd $(7.8,1.6,0.7)$ \\
\hline 7 & $16.2, \mathrm{CH}_{3}$ & 2.19, brd $(0.4)$ & $21.1, \mathrm{CH}_{3}$ & $2.35, \mathrm{~s}$ \\
\hline 8 & $57.3, \mathrm{C}$ & & $57.0, \mathrm{C}$ & \\
\hline $9 a$ & $51.3, \mathrm{CH}_{2}$ & $3.13, \mathrm{~d}(5.3)$ & $50.9, \mathrm{CH}_{2}$ & $3.12, \mathrm{~d}(5.3)$ \\
\hline $9 b$ & & $2.87, \mathrm{~d}(5.3)$ & & $2.85, \mathrm{~d}(5.3)$ \\
\hline $10 \mathrm{a}$ & $65.8, \mathrm{CH}_{2}$ & $4.79, \mathrm{~d}(12.2)$ & $65.9, \mathrm{CH}_{2}$ & 4.76, d (12.2.) \\
\hline $10 \mathrm{~b}$ & & $4.48, \mathrm{~d}(12.2)$ & & $4.47, \mathrm{~d}(12.2)$ \\
\hline $1^{\prime}$ & 166.1, C & & $165.9, \mathrm{C}$ & \\
\hline $2^{\prime}$ & $129.9, \mathrm{C}$ & & $129.72, \mathrm{C}$ & \\
\hline $3^{\prime}$ & $129.8, \mathrm{CH}$ & $7.99, \mathrm{~m}$ & $129.67, \mathrm{CH}$ & $7.98, \mathrm{~m}$ \\
\hline $4^{\prime}$ & $128.5, \mathrm{CH}$ & $7.43, \mathrm{~m}$ & $128.4, \mathrm{CH}$ & $7.42, \mathrm{~m}$ \\
\hline $5^{\prime}$ & $133.3, \mathrm{CH}$ & $7.55, \mathrm{~m}$ & $133.1, \mathrm{CH}$ & $7.55, \mathrm{tt}(7.6,1.3)$ \\
\hline $6^{\prime}$ & $128.5, \mathrm{CH}$ & $7.42, \mathrm{~m}$ & $128.4, \mathrm{CH}$ & $7.42, \mathrm{~m}$ \\
\hline $7^{\prime}$ & $129.8, \mathrm{CH}$ & $7.99, \mathrm{~m}$ & $129.67, \mathrm{CH}$ & $7.98, \mathrm{~m}$ \\
\hline $1^{\prime \prime}$ & $175.9, \mathrm{C}$ & & $175.3, \mathrm{C}$ & \\
\hline $2 "$ & $34.3, \mathrm{CH}$ & 2.83, hep (7.2) & $34.2, \mathrm{CH}$ & 2.85, hep (7.0) \\
\hline $3^{\prime \prime}, 4^{\prime \prime}$ & $19.1,19.2, \mathrm{CH}_{3}$ & $1.31,1.32 \mathrm{~d}(7.2)$ & $18.9,19.0, \mathrm{CH}_{3}$ & $1.32,1.33, \mathrm{~d}(7.0)$ \\
\hline $\mathrm{OCH}_{3}$ & $55.9, \mathrm{CH}_{3}$ & $3.82, \mathrm{~s}$ & & \\
\hline
\end{tabular}

Careful analysis of the spectrum indicated long range ${ }^{1} \mathrm{H} /{ }^{1} \mathrm{H}$ couplings of $\mathrm{H}-2$ and $\mathrm{H}-6$ with the benzylic protons of the methyl group $\mathrm{C}-7\left({ }^{3} \mathrm{~J}=1.6,{ }^{4} \mathrm{~J}=0.7 \mathrm{~Hz}\right)$. The presence of the benzoate and isobutyrate esters, were evident by the presence of characteristic benzoate signals $\left(\delta_{\mathrm{H} / \mathrm{C}} 7.98 / 129.7,7.42 / 128.4\right.$ and $\left.7.55 / 133.1\right)$, and the methine septet $\left(\delta_{\mathrm{H} / \mathrm{C}} 2.85 / 34.2\right)$, and methyl doublets $\left(\delta_{\mathrm{H} / \mathrm{C}} 1.32 / 18.9,1.33 / 19.0\right)$ of the isobutyrate. The position of the ester moieties, was confirmed via $\mathrm{HMBC}^{2} J$ and ${ }^{3} J$ long range couplings.

Compound 4 (Figure 3) was isolated as colorless oil, whose molecular formula $\mathrm{C}_{21} \mathrm{H}_{22} \mathrm{O}_{5}$ was established according with its HRDARTMS, which shows an $[\mathrm{M}+\mathrm{H}]^{+}$exact mass peak at $\mathrm{m} / \mathrm{z}$ 355.15360 (calculated for $\mathrm{C}_{21} \mathrm{H}_{23} \mathrm{O}_{5}, 355.15455$ ). The ${ }^{1} \mathrm{H}-\mathrm{NMR}$ of compound 4 (Table 3) displayed characteristic signals for the benzoate $\left(\delta_{\mathrm{H} / \mathrm{C}} 8.03 / 130.2,7.43 / 128.6\right.$ and $\left.7.55 / 133.2\right)$ and the isobutyrate $\left(\delta_{\mathrm{H} / \mathrm{C}} 2.75 / 34.2,1.27 / 19.1\right)$ esters. Two one-proton aromatic signals, which appeared as broadened singlets, at $\delta 6.81,6.74$, suggested a tetra-substituted thymol ring. The presence of two vinylic proton signals which appear as apparent quartets at $\delta 5.48(J=1.6 \mathrm{~Hz}, \mathrm{H}-9 \mathrm{a})$ and $5.25(J=1.2 \mathrm{~Hz}, \mathrm{H}-9 \mathrm{~b})$, indicated that the common epoxy group at C-8-C-9 in compounds 1-3, was replaced by an olefinic terminal methylene. The observed small $J$ values, are due to alyllic couplings with the methylene protons at C-10, which appeared as a broadened doublet of doublets at $\delta 5.0(J=1.6,1.2 \mathrm{~Hz})$. The above data, allowed the identification of compound 4 as 10-benzoyloxy-8,9-dehydro-6-hydroxy-thymol isobutyrate (4), which could be considered as the biosynthetic precursor of compound $\mathbf{1}$.

A compound with the same structure as 4 was reportedly isolated from A. glabrata by Bohlman et al. [3], but the limited published ${ }^{1} \mathrm{H}-\mathrm{NMR}$ data differ completely from those of compound 4, and are in disagreement with the structure.

Compounds 1-3 were previously isolated from A. glabrata [1,3,11], but as mentioned before, only limited NMR data were available. In this paper the structure and absolute configuration of compound 1, have been unambiguously established by NMR and single crystal X-ray diffraction, as well as, the complete assignment of the ${ }^{1} \mathrm{H}$ and ${ }^{13} \mathrm{C}-\mathrm{NMR}$ data for compounds 1-3. 

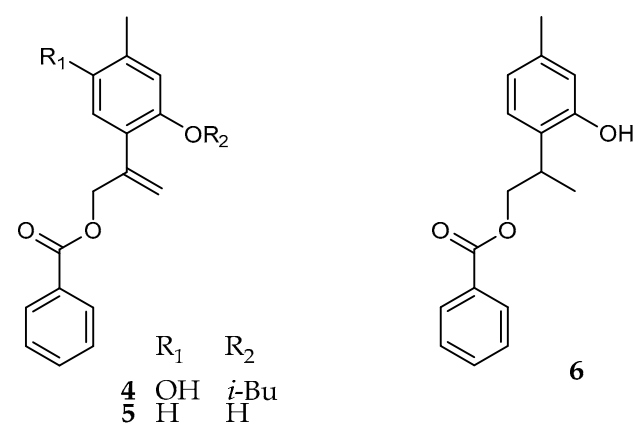

Figure 3. Chemical structures of $\mathbf{4 - 6}$.

Table 3. NMR spectroscopic data $\left({ }^{1} \mathrm{H} 400 \mathrm{MHz},{ }^{13} \mathrm{C} 100 \mathrm{MHz}, \mathrm{CDCl}_{3}\right)$ of 4-6.

\begin{tabular}{|c|c|c|c|c|c|c|}
\hline \multirow{2}{*}{ Position } & \multicolumn{2}{|c|}{4} & \multicolumn{2}{|r|}{5} & \multicolumn{2}{|r|}{6} \\
\hline & $\delta_{C}$, Type & $\delta_{\mathrm{H}}(J$ in $\mathrm{Hz})$ & $\delta_{C}$, Type & $\delta_{\mathrm{H}}(J$ in $\mathrm{Hz})$ & $\delta_{C}$, Type & $\delta_{\mathrm{H}}(J$ in $\mathrm{Hz})$ \\
\hline 1 & 125.0, C & & $140.2, \mathrm{C}$ & & 138.0, C & \\
\hline 2 & $124.9, \mathrm{CH}$ & $6.80, \mathrm{brs}$ & $116.9, \mathrm{CH}$ & $6.78, \mathrm{~d}(0.7)$ & $116.8, \mathrm{CH}$ & $6.68, \mathrm{~d}(0.8)$ \\
\hline 3 & $141.4, \mathrm{C}$ & & $153.5, \mathrm{C}$ & & 154.0, C & \\
\hline 4 & $130.9, \mathrm{C}$ & & 122.6, C & & 125.3, C & \\
\hline 5 & $115.9, \mathrm{CH}$ & $6.74, \mathrm{~s}$ & $129.3, \mathrm{CH}$ & $7.03, \mathrm{~d}(7.7)$ & $127.2, \mathrm{CH}$ & $7.10, \mathrm{~d}(7.8)$ \\
\hline 6 & 151.6, C & & $121.2, \mathrm{CH}$ & $\begin{array}{c}\text { 6.71, ddd (7.7, } \\
1.7,0.7)\end{array}$ & 121.6, C & $6.74, \operatorname{ddd}(7.6,0.8,0.4)$ \\
\hline 7 & $15.8, \mathrm{CH}_{3}$ & $2.22, \mathrm{brs}$ & $21.4, \mathrm{CH}_{3}$ & $2.32, \mathrm{~s}$ & 21.1, $\mathrm{CH}_{3}$ & $2.28, \mathrm{~s}$ \\
\hline 8 & $140.2, \mathrm{C}$ & - & $141.9, \mathrm{C}$ & & $32.4, \mathrm{C}$ & $3.50, \mathrm{dqd}(8.0,6.8,4.8)$ \\
\hline $9 a$ & 117.3, $\mathrm{CH}_{2}$ & $5.48, \mathrm{q}(1.6)$ & $116.7, \mathrm{CH}_{2}$ & $5.56, \mathrm{q}(1.6)$ & $16.7, \mathrm{CH}_{3}$ & $1.42, \mathrm{~d}(6.8)$ \\
\hline $9 b$ & & $5.25, \mathrm{q}(1.2)$ & & $5.31, \mathrm{q}(1.2)$ & & \\
\hline $10 \mathrm{a}$ & $66.7, \mathrm{CH}_{2}$ & $5.0, \mathrm{dd}(1.6,1.2)$ & 66.6, $\mathrm{CH}_{2}$ & 4.99 , dd $(1.6,1.2)$ & $70.2, \mathrm{CH}_{2}$ & $4.53, \mathrm{~d}(10.9,4.8)$ \\
\hline $10 \mathrm{~b}$ & & & & & & $4.19 \mathrm{dd}(10.9,8.0)$ \\
\hline $1^{\prime}$ & $166.3, \mathrm{C}$ & & 167.2, C & & 167.5, C & \\
\hline $2^{\prime}$ & $130.2, \mathrm{C}$ & & $129.8, \mathrm{C}$ & & $130.3, \mathrm{C}$ & \\
\hline $3^{\prime}$ & $129.8, \mathrm{CH}$ & $8.03, \mathrm{~m}$ & $129.9, \mathrm{CH}$ & $8.09, \mathrm{~m}$ & $129.8, \mathrm{CH}$ & $8.04, \mathrm{~m}$ \\
\hline $4^{\prime}$ & $128.6, \mathrm{CH}$ & $7.43, \mathrm{~m}$ & $128.7, \mathrm{CH}$ & $7.47, \mathrm{~m}$ & $128.5, \mathrm{CH}$ & $7.56, \mathrm{tt}(7.2,1.6)$ \\
\hline $5^{\prime}$ & $133.2, \mathrm{CH}$ & $7.55, \mathrm{tt}(7.4,1.4)$ & $133.6, \mathrm{CH}$ & $7.60, \mathrm{tt}(7.2,1.3)$ & $133.2, \mathrm{CH}$ & $7.44, \mathrm{~m}$ \\
\hline $6^{\prime}$ & $128.6, \mathrm{CH}$ & $7.43, \mathrm{~m}$ & $128.7, \mathrm{CH}$ & $7.47, \mathrm{~m}$ & $128.5, \mathrm{CH}$ & 7.56 , tt $(7.2,1.6)$ \\
\hline $7^{\prime}$ & $129.8, \mathrm{CH}$ & $8.03, \mathrm{~m}$ & $129.9, \mathrm{CH}$ & $8.09, \mathrm{~m}$ & $129.8, \mathrm{CH}$ & $8.04, \mathrm{~m}$ \\
\hline $1^{\prime \prime}$ & 176.1, C & & & & & \\
\hline $2^{\prime \prime}$ & $34.2, \mathrm{CH}$ & 2.75 , hep $(7.0)$ & & & & \\
\hline $3^{\prime \prime}, 4^{\prime \prime}$ & $19.1, \mathrm{CH}_{3}$ & $1.27, \mathrm{~d}(7.0)$ & & & & \\
\hline
\end{tabular}

Compounds 5 and $\mathbf{6}$ (Figure 3) are new natural thymol derivatives; they were obtained in minute amounts after repeated column chromatography and purification by thin layer chromatography. The ${ }^{1} \mathrm{H}-\mathrm{NMR}$ spectrum of 5 (Table 3 ) displayed similar features than those of compound 4, except for the lack of signals ascribed to the isobutyrate moiety and the -OH group at $\mathrm{C}-6$. The presence of an olefinic terminal methylene was evident from the two one-proton signals at $\delta 5.56(q, J=1.6, \mathrm{H}-9 \mathrm{a})$ and 5.31 ( $\mathrm{q}, J=1.2, \mathrm{H}-9 \mathrm{~b})$, both coupled with the allylic methylene protons at C-10. Thus, the structure of compound 5 was established as 10-benzoyloxy-8,9-dehydrothymol (5).

Compound 6, was identified as the dihydroderivative of 5 . Therefore, the ${ }^{1} \mathrm{H}-\mathrm{NMR}$ spectrum (Table 3), did not show the olefinic methylene signals, instead of that, the spectrum displayed a methyl doublet signal at $\delta 1.42(\mathrm{~d}, J=6.8 \mathrm{~Hz}, 3 \mathrm{H})$ as the part $\mathrm{X}_{3}$, of the spin system $\mathrm{ABMX}_{3}$, due to $\mathrm{H}_{2}-10, \mathrm{H}-8$ and $\mathrm{H}_{3}-9$ protons. One methine proton signal at $\delta 3.50$ appeared as a doublet of quartets of doublets $(J=8.0,6.8,4.8, \mathrm{~Hz}, 1 \mathrm{H})$, coupled with the methyl doublet and the methylene protons $\mathrm{H}_{2}-10$, according to the HSQC and HMBC experiments. The protons of the C-10 methylene bearing the benzoyloxy group appeared as the $\mathrm{AB}$ part of the spin system with signals at $\delta 4.19(\mathrm{dd}, J=10.8,8.0 \mathrm{~Hz})$ and 4.53 $(\mathrm{dd}, J=10.8,4.8 \mathrm{~Hz})$. Consequently, the structure of compound 6 , was established as 10-benzoyloxy thymol (6), and represents a new natural thymol derivative. 
Compound 7 (Figure 4) was obtained as colorless oil, whose ${ }^{1} \mathrm{H}$ and ${ }^{13} \mathrm{C}-\mathrm{NMR}$ spectra (Table 4) displayed similar spectral features as compound 1. Two one-proton aromatic singlets at $\delta 6.66$ and 6.60 indicating the tetrasubstitution of the thymol ring. The presence of a benzoate and an isobutyrate was evident from their characteristic signals $\left(\delta_{\mathrm{H} / \mathrm{C}} 7.98 / 129.9,7.41 / 128.7,7.55 / 133.6\right)$, for the benzoate and $\left(\delta_{\mathrm{H} / \mathrm{C}} 2.53 / 34.1,1.05,1.08 / 18.9,19.0\right)$ due to the isobutyrate. The main differences between 1 and 7 were the multiplicity and chemical shifts of signals due to the methylene groups bearing the oxygen functionalities. The ${ }^{1} \mathrm{H}-\mathrm{NMR}$ spectrum displayed two $\mathrm{AB}$ spin systems with signals centered at $\delta_{\mathrm{H}} 4.51,4.58(\mathrm{~d}, J=11.6, \mathrm{C}-9)$, and $4.64,4.68(\mathrm{~d}, J=12.0, \mathrm{C}-10)$, coupled with the methylene carbon signals at $\delta_{C} 67.5$ and 68.1 , according to the HSQC spectrum, respectively. In the HMBC experiment, the proton signals of both $\mathrm{AB}$ methylene groups, showed ${ }^{2} \mathrm{~J}$ and ${ }^{3} \mathrm{~J}$ long range couplings with the tertiary carbon signals at $\delta_{C} 78.3(\mathrm{C}-8)$ and $120.3(\mathrm{C}-4)$. On the other hand the AB system centered at $\delta 4.55$ was coupled to the carbonyl at $\delta 177.9$, which in turn, was coupled with the methine heptet and methyl doublets of the isobutyrate $\left(\delta_{\mathrm{H} / \mathrm{C}} 2.53 / 34.1,1.05,1.08 / 19.0\right)$, while the one, centered at $\delta 4.66$ showed couplings with the carbonyl at $\delta 167.1$, that in turn was, coupled with the benzoate protons $\mathrm{H}-3^{\prime} / 7^{\prime}\left(\delta_{\mathrm{H} / \mathrm{C}} 7.98 / 129.9\right)$. Thus, the isobutyrate is attached to C-9, and the benzoate at C-10. According with the above data, the structure of compound 7 was established as 10-benzoyloxy-6,8-dihydroxy-9-isobutyryloxythymol (7).

Table 4. NMR spectroscopic data $\left({ }^{1} \mathrm{H} 400 \mathrm{MHz},{ }^{13} \mathrm{C} 100 \mathrm{MHz}, \mathrm{CDCl}_{3}\right)$ of 7 and $7 \mathbf{a}$.

\begin{tabular}{|c|c|c|c|c|c|}
\hline \multirow{2}{*}{ Position } & \multicolumn{3}{|c|}{7} & \multicolumn{2}{|c|}{$7 a$} \\
\hline & $\delta_{C}$, Type & $\delta_{\mathrm{H}}(J$ in $\mathrm{Hz})$ & HMBC & $\delta_{C}$, Type & $\delta_{\mathrm{H}}(J$ in $\mathrm{Hz})$ \\
\hline 1 & $126.2, \mathrm{C}$ & & & $132.3, \mathrm{C}$ & \\
\hline 2 & $120.2, \mathrm{CH}$ & 6.66, brs & $3,4,6,7$ & $126.7, \mathrm{CH}$ & $6.96, \mathrm{~d}(0.7)$ \\
\hline 3 & $149.8, \mathrm{C}$ & & & $145.3, \mathrm{C}$ & \\
\hline 4 & $120.3, \mathrm{C}$ & & & 127.7, C & \\
\hline 5 & 113.0, $\mathrm{CH}$ & $6.60, \mathrm{~s}$ & $1,3,6,8$ & $121.8, \mathrm{CH}$ & $7.16, \mathrm{~s}$ \\
\hline 6 & $147.2, \mathrm{C}$ & & & $147.1, \mathrm{C}$ & \\
\hline 7 & $15.7, \mathrm{CH}_{3}$ & 2.17 , brs & 1,2 & $16.1, \mathrm{CH}_{3}$ & $1.63, \mathrm{brs}$ \\
\hline 8 & $78.3, \mathrm{C}$ & & & $80.8, \mathrm{C}$ & \\
\hline $9 \mathrm{a}$ & $67.5, \mathrm{CH}_{2}$ & $4.58, \mathrm{~d}(11.9)$ & $4,8,10,1^{\prime \prime}$ & $62.9, \mathrm{CH}_{2}$ & $4.96, \mathrm{~d}(11.4)$ \\
\hline $9 b$ & & $4.51, \mathrm{~d}(11.9)$ & $4,8,10,1^{\prime \prime}$ & & $4.81, \mathrm{~d}(11.4)$ \\
\hline $10 \mathrm{a}$ & $68.1, \mathrm{CH}_{2}$ & $4.68 \mathrm{~d}(12.0)$ & $1^{\prime}, 4,8,9$ & 63.6, $\mathrm{CH}_{2}$ & $5.12, \mathrm{~d}(11.4)$ \\
\hline $10 \mathrm{~b}$ & & $4.65, \mathrm{~d}(12.0)$ & $1^{\prime}, 4,8,9$ & & $4.91, \mathrm{~d}(11.4)$ \\
\hline $1^{\prime}$ & $167.0, \mathrm{C}$ & & & $165.8, \mathrm{C}$ & \\
\hline $2^{\prime}$ & 129.1, C & & & 129.6, C & \\
\hline $3^{\prime}$ & $129.9, \mathrm{CH}$ & $7.98, \mathrm{~m}$ & $1^{\prime}, 5^{\prime}, 7^{\prime}$ & $129.8, \mathrm{CH}$ & $7.95, \mathrm{~m}$ \\
\hline $4^{\prime}$ & $128.7, \mathrm{CH}$ & $7.41, \mathrm{~m}$ & $3^{\prime}, 5^{\prime}, 7^{\prime}$ & $128.6, \mathrm{CH}$ & $7.43, \mathrm{~m}$ \\
\hline $5^{\prime}$ & 133.6, CH & $7.55, \mathrm{tt}(7.4,1.3)$ & $3^{\prime}, 7^{\prime}$ & $133.4, \mathrm{CH}$ & $7.55, \mathrm{tt}(7.5,1.3)$ \\
\hline $6^{\prime}$ & 128.7, CH & $7.41, \mathrm{~m}$ & $3^{\prime}, 5^{\prime}, 7^{\prime}$ & $128.6, \mathrm{CH}$ & $7.43, \mathrm{~m}$ \\
\hline $7^{\prime}$ & $129.9, \mathrm{CH}$ & $7.98, \mathrm{~m}$ & $1^{\prime}, 5^{\prime}, 3^{\prime}$ & $129.8, \mathrm{CH}$ & $7.95, \mathrm{~m}$ \\
\hline $1^{\prime \prime}$ & $177.9, \mathrm{C}$ & & & $176.3, \mathrm{C}$ & \\
\hline $2^{\prime \prime}$ & $34.1, \mathrm{CH}$ & 2.53, hep $(7.0)$ & $1^{\prime \prime}, 3^{\prime \prime}, 4^{\prime \prime}$ & $34.0, \mathrm{CH}$ & 2.52, hep $(7.0)$ \\
\hline $3^{\prime \prime}, 4^{\prime \prime}$ & 18.9. $19.0, \mathrm{CH}_{3}$ & $1.05,1.08, \mathrm{~d}(7.0)$ & $1^{\prime \prime}, 2^{\prime \prime}$ & $18.8,18.9, \mathrm{CH}_{3}$ & $1.08,1.10, \mathrm{~d}(7.0)$ \\
\hline $3-\mathrm{OCOCH}_{3}$ & & & & $21.3,169.4, \mathrm{CH}_{3}, \mathrm{CO}$ & $2.38, \mathrm{~s}$ \\
\hline $6-\mathrm{OCO}^{-\mathrm{CH}_{3}}$ & & & & $20.9,168.8, \mathrm{CH}_{3}, \mathrm{CO}$ & $2.31, \mathrm{~s}$ \\
\hline $8-\mathrm{OCO}^{-\mathrm{CH}_{3}}$ & & & & $21.4,168.8, \mathrm{CH}_{3}, \mathrm{CO}$ & $2.00, \mathrm{~s}$ \\
\hline
\end{tabular}

Regarding the AC of compounds 6 and 7, the optical rotation and ECD values of compound 6 and $\mathbf{7}$ were similar to those of compounds $\mathbf{1}$ and $\mathbf{9}$ with established $8 S$ configuration, suggesting the same configuration for compounds 6 and 7. Further investigation is nevertheless desirable in order to confirm the above assumption.

The HRDARTMS of 7, did not show the $\mathrm{C}_{21} \mathrm{H}_{25} \mathrm{O}_{7}[\mathrm{M}+\mathrm{H}]^{+}$ion at $m / z 389$, instead of that, it displayed the $\left[\mathrm{M}-\mathrm{H}_{2} \mathrm{O}+\mathrm{H}\right]^{+}$, ion peak at $m / z 371.14833$ in agreement with a molecular formula $\mathrm{C}_{21} \mathrm{H}_{23} \mathrm{O}_{6}$ (calculated 371.14946), due to the loss of water from the molecular ion. It is documented that some of these compounds are artifacts originated by the hydrolytic opening of the oxirane-ring 
followed by transesterification from O-3 to O-9 during the isolation process, or after purification [12,13]. In case of compound 7, it is indeed an artifact, since it was obtained from compound 1, after storing at room temperature for some time.

Recently a thymol derivative isolated from A. glabrata has been described [14]. Its proposed structure 8, was established on the basis of MS, ${ }^{1} \mathrm{H}$ and ${ }^{13} \mathrm{C}-\mathrm{NMR}$ data. Comparison of the published data with those of compound 7, showed to be identical. Therefore, the structure 8 must be revised, and changed to the structure 7 (Figure 4).
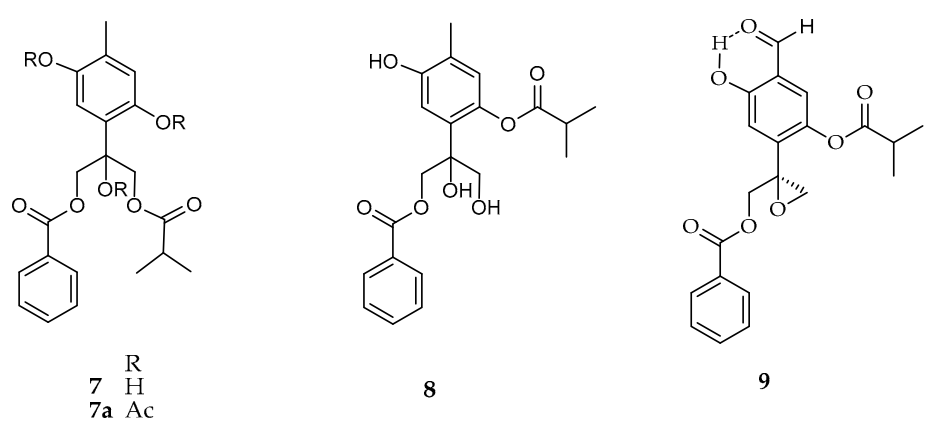

Figure 4. Chemical structures of $\mathbf{7 - 9 .}$

Acetylation of 7 with pyridine and acetic anhydride yielded compound 7 a (Figure 4 ). The ${ }^{1} \mathrm{H}$ and ${ }^{13} \mathrm{C}$-NMR spectra (Table 4 ) of 7a displayed features similar to those of 7, except for the presence of three sharp methyl singlet at $\delta 2.00,2.31,2.38$ in the ${ }^{1} \mathrm{H}-\mathrm{NMR}$ spectrum, which showed couplings with the methyl carbon signals at $\delta 21.4,20.9$ and 21.3 in the HSQC experiment, and with the carbonyl carbons at 168.8, 168.8 and 169.4, in the HMBC experiment, respectively. In addition, downfield shifts of the aromatic protons $\mathrm{H}-2, \mathrm{H}-5$ and the methylene protons of $\mathrm{CH}_{2}-9$ and $\mathrm{CH}_{2}-10$, inherent to the presence of the acetyl groups, were observed.

Compounds 1-4, 7 and 1a were investigated for antiprotozoal activity (Table 5) against Entamoeba histolytica and Giardia lamblia. Compound $\mathbf{1}$ and its derivative $\mathbf{1 a}$ showed selectivity and good antiprotozoal activity on Entamoeba histolytica trophozoites, being their effects similar to emetine and metronidazole, two antiprotozoal drugs used as controls. In contrast, in the case of Giardia lamblia both compounds showed moderate antigiardial activity. The remaining compounds $2-4,7$, and pectolinaringenin showed moderate antiprotozoal activity on both protozoa.

Table 5. In vitro antiprotozoal activity and inhibition of hyperperistalsis of thymol derivatives.

\begin{tabular}{|c|c|c|c|}
\hline \multirow{2}{*}{ Compound } & \multicolumn{2}{|c|}{$\mathrm{IC}_{50} \mu \mathrm{M}(\mathrm{CI})^{\mathrm{a}}$} & \multirow{2}{*}{$\begin{array}{c}\mathrm{ID}_{50} \mu \mathrm{mol} / \mathrm{kg} \pm \mathrm{SD}^{\mathrm{b}} \\
\text { Inhibition of Hyperperistalsis }\end{array}$} \\
\hline & Entamoeba histolytica & Giardia lamblia & \\
\hline 1 & $1.6(1.8-1.57)$ & $36.9(38.3-5.9)$ * & $2.000 \pm 0.003^{* *}$ \\
\hline $1 \mathbf{a}$ & $0.84(0.87-0.80)$ & $24.2(24.7-24.0) *$ & $0.810 \pm 0.021 * *$ \\
\hline 2 & $169.6(171.3-168.9)^{*}$ & $191.2(192.1-190.8)$ * & $0.457 \pm 0.004 * *$ \\
\hline 3 & $25.9(26.2-25.7) *$ & $48.3(48.4-45.4)^{*}$ & $0.740 \pm 0.003^{* *}$ \\
\hline 4 & $61.2(62.3-59.8) *$ & $68.069 .7-67.4)^{*}$ & $1.430 \pm 0.006^{* *}$ \\
\hline 7 & $45.6(46.9-44.3) *$ & $60.7(62.3-56.9) *$ & $0.380 \pm 0.003 * *$ \\
\hline Pectolinaringenin & $43.6(44.9-41.9) *$ & $68.7(70.3-67.4) *$ & $0.598 \pm 0.001 * *$ \\
\hline $9^{c}$ & $184.9(186.9-180.7)$ * & $167.4(168.7-165.8)^{*}$ & $0.85 \pm 0.005$ \\
\hline Emetine $^{\mathrm{d}}$ & $2.18(2.2-2.14)$ & $0.83(0.87-0.82)$ & \\
\hline Metronidazole $^{\mathrm{d}}$ & $0.23(0.58-0.17)$ & $1.22(1.57-0.81)$ & \\
\hline Quercetin & - & - & $1.1 \pm 0.001$ \\
\hline Loperamide hydrochloride ${ }^{d}$ & - & - & $0.2 \pm 0.001$ \\
\hline
\end{tabular}

${ }^{a}$ Results are expressed as mean $(n=6), \mathrm{CI}=95 \%$ confidence intervals; ${ }^{*} p<0.05$ compared to emetine and metronidazole; ${ }^{\mathrm{b}}$ Results are expressed as mean $(n=6) \pm \mathrm{SD} ;{ }^{* *} p<0.05$ compared to loperamide hydrochloride. ${ }^{\mathrm{c}}$ See ref. $7{ }^{\mathrm{d}}$ Positive controls. 
Compounds 1-4, 7 and 1a were also tested on the charcoal-gum acacia-induced hyperperistalsis model in rats. Compounds $\mathbf{1}$ and $\mathbf{4}$ showed moderate inhibitory activity on hyperpropulsive movement of the small intestine in rats with activities comparable to quercetin (Table 5). In addition, the remaining compounds 1a-3, 7, and pectolinaringenin showed high inhibitory activity but lower that of loperamide hydrochloride, antidiarrheal drug used as positive control. It is important to point out that the presence of an acetate group at the C-6 position in thymol derivative 1a seems to be important for the inhibition of hyperperistalsis and antiprotozoal activity. Finally, the antidiarrheic properties reputed for Ageratina glabrata in Mexican traditional medicine may be due to the presence of thymol derivatives 1-4, 7 and the flavonoid, pectolinaringenin.

\section{Materials and Methods}

\subsection{General Procedures}

Melting points were measured on a Fisher-Johns apparatus (Fisher Scientific Company, Pittsburgh, PA, USA) and are uncorrected. Optical rotations were measured on a 323 polarimeter (Perkin Elmer Inc., London, UK). Ultraviolet absorptions were recorded on a UV 160U spectrophotometer (Shimadzu, Kyoto, Japan). IR spectra were obtained on a Tensor 27 spectrometer (Bruker, Ettlingen, Germany). The 1D and 2D NMR experiments were performed on a Bruker Advance III spectrometer (Bruker) at $400 \mathrm{MHz}$ for ${ }^{1} \mathrm{H}$ and $100 \mathrm{MHz}$ for ${ }^{13} \mathrm{C}$. Chemical shifts were referenced to TMS and $J$ values are given in Hz. The HRDARTMS data were recorded on an AccuTOF JMS-T100LC mass spectrometer (Jeol Ltd., Tokyo, Japan). Prep TLC was carried out on precoated Sil G/UV254 plates (Macherey Nagel, Düren, Germany) of $1.0 \mathrm{~mm}$ thickness. Silica gel 230-400 mesh (Macherey-Nagel), Sephadex LH-20 (Pharmacia Biotech AB, Uppsala, Sweden) and octadecyl functionalized silica gel (Sigma Aldrich, St. Louis, MO, USA) were used for column chromatography. The X-ray data were collected on a D8 Venture k-geometry diffractometer (Bruker).

\subsection{Plant Material}

Ageratina glabrata was collected at Cuernavaca, Morelos, Mexico, in February 2015. Plant material was identified by Oscar Hinojosa Espinoza, and a voucher specimen (MEXU-1 437 258) was deposited at the National Herbarium (MEXU) of the Instituto de Biologia, UNAM.

\subsection{Extraction, Isolation and Characterization}

The air-dried and powdered leaves of A. glabrata $(690 \mathrm{~g})$ were extracted $\mathrm{CH}_{2} \mathrm{Cl}_{2}(2 \mathrm{~L} \times 3$ times $)$ at room temperature for $48 \mathrm{~h}$. The extract was concentrated at reduced pressure to yield $18 \mathrm{~g}$ of residue. The crude extract was subjected to column chromatography (CC) on silica gel using gradient elution with EtOAc-hexanes (80:20) to obtain 29 eluates, $150 \mathrm{~mL}$ each, which were combined into 17 major fractions (A-Q) by TLC evaluation. Pectolinarigenin $(50.8 \mathrm{mg})$ crystalized from fraction N. Fraction B (2.78 g) was subjected to CC on silica gel using gradient elution with EtOAc-hexanes (90:10) to obtain 55 eluates, $150 \mathrm{~mL}$ each, which were combined in 25 major fractions (BA-BX). Compound 1 (450 mg) crystalized from fractions BG to BJ. Fraction BD $(725 \mathrm{mg})$ was further fractionated over silica gel using dichloromethane as eluent to obtain six major fractions (BDA-BDF), fraction BDD (64.5 mg) was subjected to silica gel TLC eluting with hexanes-EtOAc (70:30) to give compound 2 (17.9 mg). Fraction BG (261.6 mg) was subjected to silica gel CC eluting with dichloromethane:acetone (95:5) to give six major fractions (BGA-BGF). Fraction BGB was subjected to silica gel TLC eluting with dichloromethane-acetone (99:1) to give compound 3 (4.8 mg). Fraction C (120 mg) was separated by CC on silica gel eluted with dichloromethane-acetone (0:100-100:0) to obtain seven fractions (CA-CG). Compound 5 (5.0 mg)was identified in fraction CA. Fraction B was subjected to silica gel TLC eluting with dichloromethane to obtain compound $6(9.8 \mathrm{mg})$. Pure $4(13.3 \mathrm{mg})$ was obtained from fraction CE. Fraction G (889 mg) was subfractionated over a Sephadex LH-20 column, using MeOH as eluent to give five fractions (GA-GE). Benzoic acid $(50.6 \mathrm{mg})$ crystalized from fraction GA. Ilicic acid was obtain 
as pure compound from fraction GB. Fraction GC was subjected to silica gel CC using $\mathrm{CH}_{2} \mathrm{Cl}_{2}$ as eluent to obtain seven fractions (GCA-GCG). Pure compound 7 (24.3 mg) was obtained from fraction GCD.

(8S)-10-Benzoyloxy-8,9-epoxy-6-hydroxythymol isobutyrate (1). Colorless crystals $\left(\mathrm{CH}_{2} \mathrm{Cl}_{2}\right.$-hexane); m.p. 110-112 ${ }^{\circ} \mathrm{C} ;[\alpha]_{589}+14.5$ (c 0.001, MeOH); UV (MeOH) $\lambda_{\max }(\log \varepsilon) 204$ (4.71), 225 (4.52), 280 (3.30) nm; $\operatorname{ECD}(\mathrm{MeOH}) \lambda_{\max }(\Delta \varepsilon): 204$ (-3.2), 209 (0.2), 226 (-1.4), 253 (0.3); IR $\left(\mathrm{CHCl}_{3}\right) v_{\max }$ 3599, 2980, 1752, $1722,1273 \mathrm{~cm}^{-1} ;{ }^{1} \mathrm{H}$ and ${ }^{13} \mathrm{C}-\mathrm{NMR}\left(\mathrm{CDCl}_{3}\right)$ see Table 1 ; HRDARTMS $\mathrm{m} / z 371.15003$ (calculated for $\left.\mathrm{C}_{21} \mathrm{H}_{22} \mathrm{O}_{6}+\mathrm{H}, 471.14946\right)$.

10-Benzoyloxy-8,9-epoxy-6-acetyloxythymol isobutyrate (1a). Colorless oil; $[\alpha]_{589}+14.7$ (c $\left.0.002, \mathrm{MeOH}\right)$; UV (MeOH) $\lambda_{\max }(\log \varepsilon) 203$ (4.47), 252 (4.52), 273 (4.51) nm; ECD (MeOH) $\lambda_{\max }(\Delta \varepsilon): 202(-10.5), 224$ (-2.9), 244 (0.4); IR $\left(\mathrm{CHCl}_{3}\right) \nu_{\max } 2979,2937,1757,1721,1270 \mathrm{~cm}^{-1} ;{ }^{1} \mathrm{H}$ and ${ }^{13} \mathrm{C}-\mathrm{NMR}\left(\mathrm{CDCl}_{3}\right)$ see Table 1; HRDARTMS $m / z 413.16040$ (calculated for $\mathrm{C}_{23} \mathrm{H}_{24} \mathrm{O}_{7}+\mathrm{H}, 413.16003$ ).

10-Benzoyloxy-8,9-epoxy-6-methoxythymol isobutyrate (2). Colorless oil; $[\alpha]_{589}+14.6$ (c $\left.0.0015, \mathrm{CHCl}_{3}\right)$; UV (MeOH) $\lambda_{\max }(\log \varepsilon) 204$ (4.54), 225 (4.34), 276 ( 3.70$)$ nm; ECD (MeOH) $\lambda_{\max }(\Delta \varepsilon): 204(-6.3)$, 230 (-1.1), 250 (0.2); IR $\left(\mathrm{CHCl}_{3}\right) v_{\max } 2979,2938,1751,1722,1272 \mathrm{~cm}^{-1} ;{ }^{1} \mathrm{H}$ and ${ }^{13} \mathrm{C}-\mathrm{NMR}\left(\mathrm{CDCl}_{3}\right)$ see Table 2; HRDARTMS $m / z 385.16429$ (calculated for $\mathrm{C}_{22} \mathrm{H}_{24} \mathrm{O}_{6}+\mathrm{H}, 385.16511$ ).

10-Benzoyloxy-8,9-epoxythymol isobutyrate (3). Colorless oil; $[\alpha]_{589}-3.9$ (c $\left.0.002, \mathrm{CHCl}_{3}\right) ; \mathrm{UV}(\mathrm{MeOH})$ $\lambda_{\max }(\log \varepsilon) 203$ (4.27), 221 (4.16), nm; ECD (MeOH) $\lambda_{\max }(\Delta \varepsilon): 205$ (1.1), 215 (-0.5); IR $\left(\mathrm{CHCl}_{3}\right) v_{\max }$ 2976, 2938, 1757, 1723, $1271 \mathrm{~cm}^{-1} ;{ }^{1} \mathrm{H}$ and ${ }^{13} \mathrm{C}-\mathrm{NMR}\left(\mathrm{CDCl}_{3}\right)$ see Table 2; HRDARTMS m/z 355.15516 (calculated for $\left.\mathrm{C}_{21} \mathrm{H}_{22} \mathrm{O}_{5}+\mathrm{H}, 355.15455\right)$.

10-Benzoyloxy-8,9-dehydro-6-hydroxythymol isobutyrate (4). Colorless oil; UV (MeOH) $\lambda_{\max }(\log \varepsilon) 204$ (4.31), 225 (4.23), 276 (3.58) nm; IR $\left(\mathrm{CHCl}_{3}\right) v_{\max } 3522,2953,2927,1757,1713,1291 \mathrm{~cm}^{-1} ;{ }^{1} \mathrm{H}$ and ${ }^{13} \mathrm{C}-\mathrm{NMR}\left(\mathrm{CDCl}_{3}\right)$ see Table 3; HRDARTMS $m / z 355.15360$ (calculated for $\mathrm{C}_{21} \mathrm{H}_{22} \mathrm{O}_{5}+\mathrm{H}, 355.15455$ ).

10-Benzoyloxy-8,9-dehydrothymol isobutyrate (5). Colorless oil; ${ }^{1} \mathrm{H}$ and ${ }^{13} \mathrm{C}-\mathrm{NMR}\left(\mathrm{CDCl}_{3}\right)$ see Table 3.

10-Benzoyloxythymol isobutyrate (6). white powder; m.p. $94-97{ }^{\circ} \mathrm{C}[\alpha]_{589}+12.27$ (c $\left.0.002, \mathrm{CHCl}_{3}\right)$; UV (MeOH) $\lambda_{\max }(\log \varepsilon) 205$ (3.87), 224 (3.80),275 (3.21) nm; ECD (MeOH) $\lambda_{\max }(\Delta \varepsilon): 203$ (-4.3), 217 (0.5), 238 (-0.7), 277 (1.6); IR $\left(\mathrm{CHCl}_{3}\right) v_{\max } 3599,3400,2970,2928,1752,1714,1279 \mathrm{~cm}^{-1} ;{ }^{1} \mathrm{H}$ and ${ }^{13} \mathrm{C}-\mathrm{NMR}\left(\mathrm{CDCl}_{3}\right)$ see Table 3.

10-Benzoyloxy-6,8-dihydroxy-9-isobutyryloxythymol (7). Colorless oil; $[\alpha]_{589} 0.00$ (c $\left.0.001, \mathrm{CHCl}_{3}\right)$; UV (MeOH) $\lambda_{\max }(\log \varepsilon) 205$ (4.96), 228 (4.89), 293 (4.40) nm; ECD (MeOH) $\lambda_{\max }(\Delta \varepsilon): 202(-9.3), 208$ (2.0), 213 (1.2), $221(0.5)$; IR $\left(\mathrm{CHCl}_{3}\right) v_{\max } 3603,3398,2979,2936,1724,1291 \mathrm{~cm}^{-1} ;{ }^{1} \mathrm{H}$ and ${ }^{13} \mathrm{C}-\mathrm{NMR}$ $\left(\mathrm{CDCl}_{3}\right)$ see Table 4; HRDARTMS $m / z$ 371.14933 [M - $\left.\mathrm{H}_{2} \mathrm{O}\right]^{+}$(calculated for $\mathrm{C}_{21} \mathrm{H}_{23} \mathrm{O}_{6}, 371.149646$ ). ESIMS $m / z 411$.

10-Benzoyloxy-6,8-diacetyloxy-9-isobutyroyloxythymol acetate (7a). Colorless oil; $[\alpha]_{589}+3.60$ (c 0.001 , $\left.\mathrm{CHCl}_{3}\right)$; UV (MeOH) $\lambda_{\max }(\log \varepsilon) 203$ (6.32), 223 (6.16), 274 (5.27) nm; ECD (MeOH) $\lambda_{\max }(\Delta \varepsilon): 202$ (-6.9), $208(0.4), 216(-0.6), 226(-0.5), 241(0.2)$; IR $\left(\mathrm{CHCl}_{3}\right) v_{\max } 2978,2936,1759,1370,1271 \mathrm{~cm}^{-1}$; ${ }^{1} \mathrm{H}$ and ${ }^{13} \mathrm{C}-\mathrm{NMR}\left(\mathrm{CDCl}_{3}\right)$ see Table 4; DARTMS $m / z 546\left[\mathrm{M}-\mathrm{C}_{4} \mathrm{H}_{8} \mathrm{O}_{2}\right]^{+}$.

\subsection{X-ray Crystallography of Compound $\mathbf{1}$}

Colorless crystals of $0.376 \times 0.188 \times 0.098 \mathrm{~mm}^{3}$, with empirical formula $\mathrm{C}_{21} \mathrm{H}_{22} \mathrm{O}_{6}$, and $\mathrm{Mr}=370.39$, crystallized in a Monoclinic crystal system, P21, with cell parameters a $=10.0148(8) \AA$, $\mathrm{b}=7.6733(6) \AA$, and $\mathrm{c}=24.814(2) \AA . \mathrm{V}=1872.2(3) \AA^{3}, \mathrm{Z}=4, \mathrm{D}_{\text {calcd }}=1.314 \mathrm{Mg} / \mathrm{m}^{3}, \mathrm{m \mu} 0.796 \mathrm{~mm}^{-1}$, $\mathrm{F}(000)=784.0$. Compound 1 was irradiated with $\mathrm{CuK} \alpha$ radiation $(\lambda=1.54178 \AA)$ on the Bruker D8 Venture k-geometry diffractometer with microfocus $X$-ray source and Helios multilayer mirror as monochromator, using an APEX 3 program [15] at 150(2) K. Data reduction was achieved using the SAINT program [15] Totals of 23784 reflections were collected, from which $6748\left(R_{\text {int }}=0.0767\right)$ reflections were independent. Structure was solved using direct methods and then refined with the 
SHELXS and SHELXL programs [16] with full-matrix least-squares on F2, respectively. ORTEP-3 software [17] was used for the figures.

The final values $S=1.064, R_{1}=0.0479$, and $w R_{2}=0.1092$ were based on 6748 reflections observed, 499 parameters. The largest different peak and hole for 1 was 0.196 and $-0.161 \mathrm{e} \cdot \AA^{-3}$.

\subsection{Antiprotozoal Assays}

Entamoeba histolytica strain HM1-IMSS used in all experiments was grown axenically at $37^{\circ} \mathrm{C}$ in TYI-S-33 medium supplemented with 10\% heat inactivated bovine serum. In the case of Giardia lamblia, strain IMSS: 8909:1 was grown in TYI-S-33 modified medium supplemented with 10\% calf serum and bovine bile. The trophozoites were axenically maintained and for assays were employed in the log phase of growth. In vitro susceptibility tests were performed using a subculture method previously described [18]. Briefly, E. histolytica $\left(6 \times 10^{3}\right)$ or G. lamblia $\left(5 \times 10^{4}\right)$ trophozoites were incubated for $48 \mathrm{~h}$ at $37^{\circ} \mathrm{C}$ in the presence of different concentrations $(2.5-200 \mu \mathrm{g} / \mathrm{mL})$ of the crude extract or pure compounds in dimethyl sulfoxide (DMSO). Each test included metronidazole (Sigma) as standard amoebicidal and giardicidal drugs, a control (culture medium plus trophozoites and DMSO), and a blank (culture medium). After incubation, the trophozoites were detached by chilling and $50 \mu \mathrm{L}$ samples of each tube were subcultured in fresh medium for another $48 \mathrm{~h}$, without antiprotozoal samples. The final number of parasites was determined with a haemocytometer and the percentages of trophozoites growth inhibition were calculated by comparison with the control culture. The results were confirmed by a colorimetric method: the trophozoites, were washed and incubated for $45 \mathrm{~min}$ at $37^{\circ} \mathrm{C}$ in phosphate buffer saline with MTT (3-(4,5-dimethylhiazol-2-il)-2,5-diphenyl tetrazolium bromide) and phenazine methosulfate. The dye produced (formazan) was extracted and the absorbance was determined at $570 \mathrm{~nm}$. The experiments were performed in duplicate for each protozoan and repeated at least three times. The in vitro results were classified as follows: if the samples displayed an $\mathrm{IC}_{50}$ less than $20 \mu \mathrm{M}$, the antiprotozoal activity was considered good, from 21 to $160 \mu \mathrm{M}$ the antiprotozoal activity was considered moderate, from 161 to $200 \mu \mathrm{M}$ the antiprotozoal activity was considered weak and over $200 \mu \mathrm{M} / \mathrm{mL}$ the samples were considered inactive. Data were analyzed using probit analysis. The percentage of trophozoites surviving was calculated by comparison with the growth in the control group. The plot of probit against log concentration was made; the best straight line was determined by regression analysis and the $50 \%$ inhibitory concentration $\left(\mathrm{IC}_{50}\right)$ values were calculated. The regression coefficient, its level of significance $(p<0.05$ indicates significant difference between group) and correlation coefficient were calculated and 95\% CI values determined.

\subsection{Animals}

Male Sprague-Dawley rats (200-250 g) were obtained from the animal house of the IMSS. These studies were conducted with the approval of the Specialty Hospital Bio-Ethical Committee of the National Medical Center "Siglo XXI" from IMSS (Approval No.: R-2012-3601-182). Investigation using experimental animals was conducted in accordance with the official Mexican norm NOM 0062-ZOO-1999 entitled Technical specifications for the production, care and use of laboratory animals [19]. They were fasted overnight but tap water was available ad libitum until the start of the experiments.

\subsection{Effect on Charcoal-Gum Acacia-Induced Hyperperistalsis}

The method, described by Williamson et al. [20] was adopted to study the effect of the compounds on hyperperistalsis in rats. The test animals were divided into control group and test groups containing six rats in each group. Rats were treated orally with each compound $(0.01,0.1,1.0,10,20,40 \mathrm{mg} / \mathrm{kg}$ in $1 \mathrm{~mL}$ of a $2 \%$ dimethyl sulfoxide (DMSO) solution in water), or vehicle ( $1 \mathrm{~mL}$ of a $2 \%$ DMSO solution in water) or loperamide hydrochloride (Sigma) $(0.1,1.0,10,20,40 \mathrm{mg} / \mathrm{kg}$ in $1 \mathrm{~mL}$ of a $2 \%$ DMSO solution in water). After $20 \mathrm{~min}$, each of these animals was given $1 \mathrm{~mL}$ of charcoal meal ( $10 \%$ charcoal suspension in $5 \%$ aqueous arabic gum) by oral route. All animals were sacrificed 
after $30 \mathrm{~min}$, the stomach and small intestine were removed and extended on a clean glass surface. The distance moved by the charcoal meal from the pylorus was measured and then expressed as a percentage of the distance from the pylorus to the caecum. After, the plot of percentage of inhibition against concentration was made; the best straight line was determined by regression analysis and the $50 \%$ inhibitory concentration $\left(\mathrm{IC}_{50}\right)$ values were calculated. The regression coefficient, its level of significance $(p)$ and correlation coefficient were calculated. The experiments were performed six times for each concentration. $\mathrm{IC}_{50}$ values are mean \pm S.E.M. $p<0.05$ (1-way ANOVA followed by Dunnett's post hoc test), GraphPad Prism Version 5.03 (GraphPad Software Inc., La Jolla, CA, USA) was used.

Supplementary Materials: Supplementary materials can be accessed at: http://www.mdpi.com/1420-3049/21/ 9/1132/s1.

Acknowledgments: The authors acknowledge H. Rios, I. Chávez, B. Quiroz, E. Huerta, A. Peña, R. Patiño, L. Velasco, J. Pérez and C. García for collecting NMR, UV, IR, and MS data.

Author Contributions: Valeria J. Vázquez-Heredia, Celia Bustos-Brito, José S. Calderón, Baldomero Esquivel and Leovigildo Quijano, participated in the isolation and structure elucidation, preparation and revision of the manuscript. Simon Hernández-Ortega participated in the collection of $X$ ray data. Fernando Calzada and Lilian Yépez-Mulia, participated in the performance of anti-protozoan assays and their data statistic treatment. Fernando Calzada and Normand Garcia-Hernandez participated in the performance of antipropulsive assays and their data statistic treatment. All co-authors participated equally and substantially to the paper.

Conflicts of Interest: The authors declare no conflict of interest.

\section{References}

1. De Vivar, A.R.; Cuevas, L.A.; Guerrero, C. Eupaglabrina, un nuevo terpeno aislado de Eupatorium glabratum. Rev. Latinoam. Chem. 1971, 2, 32-34.

2. Guerrero, C.; Silva, M.; Maldonado, E.; Martinez, M. Acido eupaglabrico un Nuevo compuesto aislado de Eupatorium glabratum H.B.K. Rev. Latinoam. Chem. 1978, 9, 71-75.

3. Bohlmann, F.; Jakupovic, J.; Lonitz, M. Naturally Ocurring Terpene Derivatives, 76, On Constituents of the Eupatorium group. Chem. Ber. 1977, 110, 301-314. [CrossRef]

4. Pimienta-Rámirez, L.; García-Rodriguez, Y.M.; Rios-Ramirez, E.M.; Linding-Cisneros, R.; Espinoza-Garcia, F.J. Chemical composition and evaluation of the essential oil from Eupatorium glabratum as biopesticide against Sitophilus zeamais and several stored maize fungi. J. Essent. Oil Res. 2016, 28, 113-120. [CrossRef]

5. Garcia-Sanchez, E.; Ramirez-Lopez, C.B.; Martinez-Muñoz, R.E.; Flores-Garcia, A.; del Rio, R.E.; Martinez-Pacheco, M.M. Antibacterial activity of some medicinal Eupatorium species against antibiotic resistant pathogenic bacteria. Polibotánica 2015, 39, 91-101. [CrossRef]

6. García, P.G.; del Río, R.E.; Guzmán, M.R.; Martinez, G.M.I.; Scior, T.R.F. Preliminary studies on the analgesic effect of leaf extract from Ageratina glabrata in two thermal models of acute pain. Rev. Mex. Cienc. Farm. 2011, 42, 45-51.

7. Bustos-Brito, C.; Sánchez-Castellanos, M.; Esquivel, B.; Calderón, J.S.; Calzada, F.; Yépez-Mulia, L.; Hernández, A.B.; Joseph-Nathan, P.; Cuevas, G.; Quijano, L. Structure, absolute configuration, and antidiarrheal activity of a thymol derivative from Ageratina cylindrica. J. Nat. Prod. 2014, 77, 358-363. [CrossRef] [PubMed]

8. Bustos-Brito, C.; Sánchez-Castellanos, M.; Esquivel, B.; Calderón, J.S.; Calzada, F.; Yépez-Mulia, L.; Joseph-Nathan, P.; Cuevas, G.; Quijano, L. ent-Kaurene Glycosides from Ageratina cylindrica. J. Nat. Prod. 2015, 78, 2580-2587. [PubMed]

9. Deng, Y.R.; Song, A.X.; Wang, H.Q. Chemical Components of Seriphidium santolium Poljak. J. Chin. Chem. Soc. 2004, 51, 629-636. [CrossRef]

10. Flack, H.D.; Bernardinelli, G. The use of X-ray chrystallography to determine absolute configuration. Chirality 2008, 20, 681-690. [CrossRef] [PubMed]

11. Tamayo-Castillo, G.; Jakupovic, J.; Bohlmann, F.; Rojas, A.; Castro, V.; King, R.M. Germacranolides and other constituents from Ageratina species. Phytochemistry 1988, 27, 2893-2897. [CrossRef]

12. Maldonado, E.; Marquez, L.C.; Ortega, A. A thymol derivative from Calea nelsonii. Phytochemistry 1992, 31, 2527-2528. [CrossRef] 
13. Bohlmann, F.; Nuedballa, U.; Schulz, J. Über einige thymolderivate aus Gaillardia-und Helenium-arten. Chem. Ber. 1969, 102, 864-871. [CrossRef]

14. García, P.G.; García, S.E.; Martínez, G.I.; Scior, T.R.F.; Salvador, J.L.; Martínez, P.M.M.; del Río, R.E. Analgesic effect of leaf extract from Ageratina glabrata in the hot plate test. Braz. J. Pharmacog. 2011, 21, 928-935.

15. Bruker. SAINT \& APEX-2 Programs; Bruker AXS Inc.: Madison, WI, USA, 2012.

16. Sheldrick, G.M. Crystal structure refinement with SHELXL. Acta Crystallogr. Sect. C Struct. Chem. 2015, C71, 3-8. [CrossRef] [PubMed]

17. Farrugia, L.J. WinGX and ORTEP for Windows: An update. J. Appl. Crystallogr. 2012, 45, 849-854. [CrossRef]

18. Calzada, F.; Meckes, M.; Cedillo-Rivera, R.; Tapia-Contreras, A.; Mata, R. Screening of Mexican medicinal plants from antiprotozoal activity. Pharm. Biol. 1998, 36, 305-309. [CrossRef]

19. Norma Oficial Mexicana NOM-062-ZOO-1999, Especificaciones Técnicas Para la Producción, Cuidado y Uso de Los Animales de Laboratorio; Diario Oficial de la Federación: México City, México, 2001.

20. Williamson, E.M.; Okpako, D.T.; Evans, F.J. Pharmacological Methods in Phytotherapy Research: Selection, Preparation and Pharmacological Evaluation of Plant Material, 1st ed.; John Wiley \& Sons: Chichester, UK, 1996; Volume 1, p. 28.

Sample Availability: Samples of the compounds 1, 1a,2, 3 and 7 are available from the authors.

(C) 2016 by the authors; licensee MDPI, Basel, Switzerland. This article is an open access article distributed under the terms and conditions of the Creative Commons Attribution (CC-BY) license (http:/ / creativecommons.org/licenses/by/4.0/). 